SHORT COMMUNICATION

\title{
Living Cationic Polymerization of Vinyl Ethers Using a Strong Lewis Acid without Stabilizing Additives: Effective Interaction of Monomers with Growing Ends and/or $\mathrm{SnCl}_{4}$
}

\author{
By Motomasa YonezumI, ${ }^{1}$ Shokyoku KANAOKA,${ }^{1}$ Satoshi OKUMoto,${ }^{2}$ and Sadahito Aoshima ${ }^{1, *}$
}

KEY WORDS: Living Polymerization / Cationic Polymerization / Vinyl Ether / Tin(IV) Chloride / Added Base /

In general, living cationic polymerization of vinyl monomers is achieved by stabilizing unstable growing carbocations in several ways. ${ }^{1}$ For living polymerization of vinyl ethers, either a weak Lewis acid or a strong Lewis acid with an addtional external compound such as a Lewis base or a salt can be used. In the absence of additives, a strong Lewis acid such as $\mathrm{EtAlCl}_{2}, \mathrm{TiCl}_{4}$, or $\mathrm{SnCl}_{4}$ generally induces uncontrolled polymerization, except for living polymerizations using a very small amount $(0.2 \mathrm{mM})$ of $\mathrm{SnCl}_{4}$ in dichloromethane at $-78^{\circ} \mathrm{C}{ }^{2}$ For polymerization of other vinyl monomers such as styrenes and isobutene, there are few examples of living polymerization using a strong Lewis acid alone; hence the mechanism for living systems has not been determined. ${ }^{3}$

Recently, we found that living cationic polymerization of alkyl vinyl ethers was achieved at $0^{\circ} \mathrm{C}$ using a certain Lewis acid combined with a small amount of a strong base. ${ }^{4}$ This polymerization system differed from its weak base counterparts in terms of the optimum additive amount, the Lewis acid preference, and the polymerization rate. ${ }^{5}$

These findings prompted us to investigate cationic polymerizations of vinyl ethers using various metal halides in the absence of external additives, which have been utilized to stabilize propagating carbocations and Lewis acids. Much to our surprise, at $-30^{\circ} \mathrm{C}$, the sole use of $\mathrm{SnCl}_{4}$ induced fast living cationic polymerization of alkyl vinyl ethers in toluene $\left(M_{\mathrm{w}} / M_{\mathrm{n}} \sim 1.1\right)$. We herein report the polymerization behavior and mechanism for living polymerization using $\mathrm{SnCl}_{4}$ without additives based on experimental results and computational simulations.

\section{EXPERIMENTAL}

Polymerization was carried out under dry nitrogen in a baked glass tube. ${ }^{6}$ Calculation was performed using Gaussian 03. ${ }^{7}$ Other experimental procedures were described in the Supporting Information.

\section{RESULTS AND DISCUSSION}

Cationic polymerization of IBVE was carried out using an IBVE-HCl/ $\mathrm{SnCl}_{4}$ initiating system in toluene in the absence of additional external compounds at $0{ }^{\circ} \mathrm{C}$. At all $\mathrm{SnCl}_{4}$ concentrations examined, the polymerization proceeded rapidly and reached $c a .100 \%$ conversion in a few seconds with $5.0 \mathrm{mM} \mathrm{SnCl}_{4}$ or in a couple of minutes with $1.0 \mathrm{mM} \mathrm{SnCl}_{4}$. The GPC profiles of the product polymers are shown in Figure 1. With 1.0 or $2.5 \mathrm{mM}$ of $\mathrm{SnCl}_{4}$, the polymerization was less controlled. However, the lower molecular weight peak shifted toward the higher molecular weight region with further conversion, and remained relatively narrow during the polymerization. When $\left[\mathrm{SnCl}_{4}\right]_{0}=5.0 \mathrm{mM}$, a relatively controlled polymer with a unimodal MWD was obtained, although the MWD was accom-

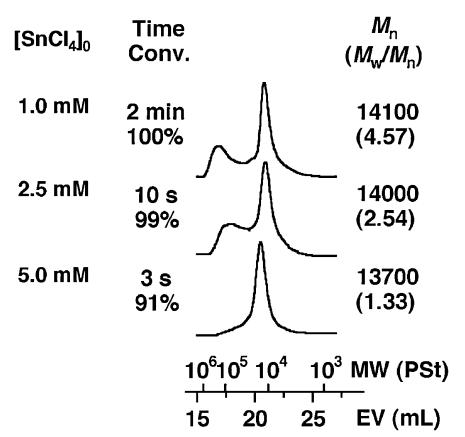

Figure 1. MWD curves for poly(IBVE) obtained using $\mathrm{SnCl}_{4}$ in toluene at $0^{\circ} \mathrm{C}:[\mathrm{IBVE}]_{0}=0.76 \mathrm{M},[\mathrm{IBVE}-\mathrm{HCl}]_{0}=4.0 \mathrm{mM},\left[\mathrm{SnCl}_{4}\right]_{0}=1.0$, 2.5 , and $5.0 \mathrm{mM}$.

panied by a slight shoulder peak in the higher molecular weight region. These results demonstrated that a long-lived propagating species was generated in the IBVE polymerization using $\mathrm{SnCl}_{4}$ without external additives.

To clarify the nature of the growing species produced with $\mathrm{SnCl}_{4}$, cationic polymerization of IBVE was investigated at $-30^{\circ} \mathrm{C}$. The polymerization was complete within only a few seconds despite the low temperature, yielding a low polydisperse polymer, the molecular weight of which was close to the calculated value $\left[M_{\mathrm{n}}(\mathrm{obsd})=18,400\right.$, $M_{\mathrm{n}}($ calcd $\left.)=20,000, M_{\mathrm{w}} / M_{\mathrm{n}}=1.08\right]$. The polymerization was further examined with the monomer/initiator $\left([\mathrm{IBVE}]_{0} /[\mathrm{IBVE}-\mathrm{HCl}]_{0}\right)$ ratio varied from 50 to 200 at a constant $\mathrm{SnCl}_{4}$ concentration. The polymerization proceeded almost quantitatively in a few seconds under all conditions, and the $M_{\mathrm{n}}$ of the obtained polymers was in direct proportion to the monomer/initiator ratio, as shown in Figure 2. These results indicated that the polymerization of IBVE proceeded in a living fashion, and that all of the polymer chains were generated from IBVE-HCl to give polymers with the predetermined $M_{\mathrm{n}}$ values based on the monomer/ initiator ratio.

To investigate the effect of Lewis acids, polymerization of IBVE in the absence of any external additive was studied using a variety of Lewis acids (Table I). $\mathrm{SnCl}_{4}$ gave polymers with narrow MWDs at each temperature, especially below $-30{ }^{\circ} \mathrm{C}\left(M_{\mathrm{w}} / M_{\mathrm{n}} \leq 1.1\right) .{ }^{8}$ On the other hand, the product polymers had uncontrolled molecular weights and/or broad MWDs even at lower temperatures when $\mathrm{EtAlCl}_{2}, \mathrm{TiCl}_{4}, \mathrm{FeCl}_{3}$, or $\mathrm{GaCl}_{3}$ was used (see Supporting Information). These results demonstrate that living cationic polymerization in the absence of additives at low temperatures was specific to the $\mathrm{SnCl}_{4}$ - based initiating system.

\footnotetext{
${ }^{1}$ Department of Macromolecular Science, Graduate School of Science, Osaka University, Toyonaka 560-0043, Japan

${ }^{2}$ Panasonic Electric Works Analysis Center Co., Ltd., 1048, Kadoma 571-8686, Japan

*To whom correspondence should be addressed (Tel: +81-6-6850-5448, Fax: +81-6-6850-5448, E-mail: aoshima@chem.sci.osaka-u.ac.jp).
} 
(A)

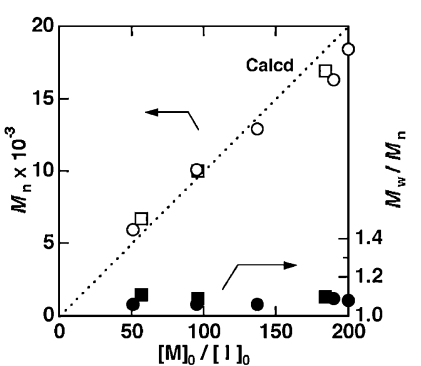

(B)

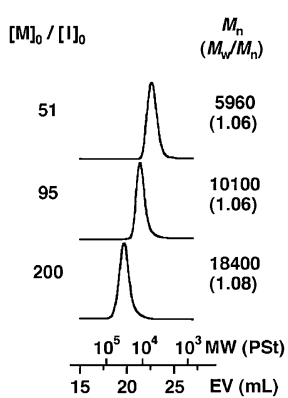

Figure 2. (A) $M_{\mathrm{n}}, M_{\mathrm{w}} / M_{\mathrm{n}}$ vs. $[\mathrm{M}]_{0} /[\mathrm{l}]_{0}$ ratio and (B) MWD curves for poly(IBVE) obtained using $\mathrm{SnCl}_{4}$ in toluene at $-30^{\circ} \mathrm{C}$ : $[\mathrm{IBVE}]_{0}=0.11-0.80 \mathrm{M}$, [IBVE- $\left.\mathrm{HCl}\right]_{0}=2.0 \mathrm{mM}(\square, \square)$ or $4.0 \mathrm{mM}$ $(\bigcirc, \bigcirc),\left[\mathrm{SnCl}_{4}\right]_{0}=5.0 \mathrm{mM}$; monomer conversion $=$ ca. $100 \%$.

Table I. Cationic Polymerization of IBVE Using Various Lewis Acids ${ }^{\mathrm{a}}$

\begin{tabular}{rcrcrcc}
\hline Run & $\begin{array}{c}\text { Lewis } \\
\text { acid }\end{array}$ & $\begin{array}{c}\text { Temp } \\
\left({ }^{\circ} \mathrm{C}\right)\end{array}$ & Time & $\begin{array}{c}\text { Conv. } \\
(\%)\end{array}$ & $M_{\mathrm{n}}{ }^{\mathrm{b}}$ & $M_{\mathrm{w}} / M_{\mathrm{n}}{ }^{\mathrm{b}}$ \\
\hline 1 & $\mathrm{SnCl}_{4}$ & 0 & $3 \mathrm{~s}$ & 91 & 13,700 & 1.33 \\
2 & $\mathrm{SnCl}_{4}$ & -30 & $10 \mathrm{~s}$ & 100 & 16,300 & 1.09 \\
3 & $\mathrm{SnCl}_{4}$ & -78 & $1 \mathrm{~min}$ & 98 & 14,500 & 1.08 \\
4 & $\mathrm{EtAlCl}_{2}$ & -30 & $10 \mathrm{~s}$ & 96 & 75,700 & 2.28 \\
5 & $\mathrm{EtAlCl}_{2}$ & -78 & $30 \mathrm{~s}$ & 100 & 76,900 & 2.16 \\
6 & $\mathrm{TiCl}_{4}$ & -30 & $10 \mathrm{~s}$ & 99 & 15,300 & 1.42 \\
7 & $\mathrm{TiCl}_{4}$ & -78 & $30 \mathrm{~s}$ & 100 & 17,900 & 1.81 \\
8 & $\mathrm{FeCl}_{3}$ & -30 & $5 \mathrm{~s}$ & 99 & 12,800 & 1.50 \\
9 & $\mathrm{FeCl}_{3}$ & -78 & $15 \mathrm{~s}$ & 99 & 17,800 & 1.37 \\
10 & $\mathrm{GaCl}_{3}$ & -30 & $4 \mathrm{~s}$ & 100 & 31,100 & 2.35 \\
11 & $\mathrm{GaCl}_{3}$ & -78 & $5 \mathrm{~s}$ & 98 & 56,700 & 1.26 \\
\hline
\end{tabular}

${ }^{\mathrm{a}}[\mathrm{IBVE}]_{0}=0.76 \mathrm{M}, \quad[\mathrm{IBVE}-\mathrm{HCl}]_{0}=4.0 \mathrm{mM}, \quad[\text { Lewis acid }]_{0}=5.0 \mathrm{mM}$, in toluene. ${ }^{\text {b}}$ Determined by GPC, polystyrene calibration.

It has been reported that diethyl ether was a much weaker Lewis base than other cyclic ethers, and required large solvent amounts to achieve living cationic polymerization of IBVE using $\mathrm{Et}_{x} \mathrm{AlCl}_{3-x}$ initiating systems. $^{6 \mathrm{~b}}$ In contrast, $\mathrm{SnCl}_{4}$ normally forms complexes with ethers, $\left(\mathrm{R}_{2} \mathrm{O}\right)_{2} \cdot \mathrm{SnCl}_{4} \cdot{ }^{9-11}$ The complex with diethyl ether was isolated and confirmed by X-ray diffraction as a stable solid with octahedral geometry. ${ }^{10}$

An NMR study also showed that $\mathrm{SnCl}_{4}$ and diethyl ether formed the complex $\left(\mathrm{Et}_{2} \mathrm{O}\right)_{2} \cdot \mathrm{SnCl}_{4}$ more strongly at lower temperatures. ${ }^{11}$ Vinyl ethers are, therefore, expected to interact sufficiently with $\mathrm{SnCl}_{4}$ and/or with carbocations, although they show lower basicity than diethyl ether. Using this information, the monomer-stabilizing mechanism by ether groups was investigated. An ab initio calculation by Gaussian 03 suggested that $\mathrm{SnCl}_{4}$ and two molecules of methyl vinyl ether (MVE) formed a stable hexacoordinated complex (Figure 3A). This rather strong coordination likely moderated the activity of $\mathrm{SnCl}_{4}$. This calculation also suggested that vinyl ether molecules likely serve as a weak Lewis base and interact with carbocations for stabilization (Figure 3B). Thus, additive-free living cationic polymerization achieved, especially at low temperatures. ${ }^{12}$

Electronic Supporting Information Available: Experimental, Figure S1, Table S1, Schemes S1, and S2. These materials are available via the Internet at http://www.spsj.or.jp/c5/pj/pj.htm

(A)

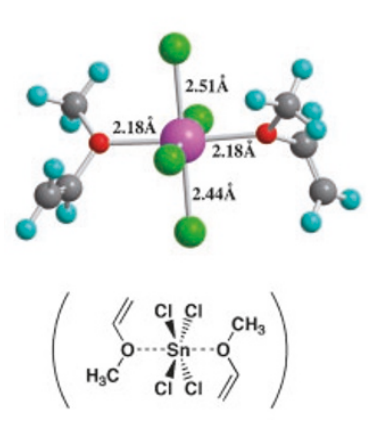

(B)

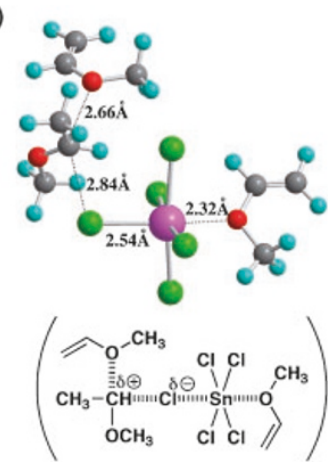

Figure 3. Geometry of (A) the 1:2 complex between $\mathrm{SnCl}_{4}$ and $\mathrm{MVE}$, and (B) the model active species for the cationic polymerization of MVE, optimized by the B3LYP/CEP-121G method.

Received: July 11, 2008

Accepted: September 30, 2008

Published: November 12, 2008

\section{REFERENCES}

1. a) J. P. Kennedy and B. Iván, "Designed Polymers by Carbocationic Macromolecular Engineering: Theory and Practice," Hanser, New York, 1992

b) "Cationic Polymerizations," K. Matyjaszewski, Ed., Marcel Dekker, New York, 1996.

2. a) H. Katayama, M. Kamigaito, M. Sawamoto, and T. Higashimura, Macromolecules, 28, 3747 (1995).

b) T. Hashimoto, T. Iwata, A. Minami, and T. Kodaira, J. Polym. Sci., Part A: Polym. Chem., 36, 3173 (1998).

3. a) O.-S. Kwon, Y.-B. Kim, S.-K. Kwon, B.-S. Choi, and S.-K. Choi, Makromol. Chem., 194, 251 (1993).

b) M.-L. Yang, K. Li, and H. D. H. Stöver, Macromol. Rapid Commun., 15, 425 (1994).

c) M. Bahadur, T. D. Shaffer, and J. R. Ashbaugh, Macromolecules, 33, 9548 (2000).

4. M. Yonezumi, N. Takano, S. Kanaoka, and S. Aoshima, J. Polym. Sci., Part A: Polym. Chem., 46, 6746 (2008).

5. a) T. Yoshida, T. Tsujino, S. Kanaoka, and S. Aoshima, J. Polym. Sci., Part A: Polym. Chem., 43, 468 (2005).

b) S. Aoshima, T. Yoshida, A. Kanazawa, S. Kanaoka, J. Polym. Sci., Part A: Polym. Chem., 45, 1801 (2007).

6. a) S. Aoshima and T. Higashimura, Macromolecules, 22, 1009 (1989).

b) Y. Kishimoto, S. Aoshima, and T. Higashimura, Macromolecules, 22, 3877 (1989).

7. Gaussian 03, Revision C.02, M. J. Frisch, Gaussian, Inc., Wallingford CT, 2004.

8. Polymerization results of other vinyl ether monomers and further discussions are described in the Supporting Information (Table S1).

9. K. Ishihara, "Lewis Acids in Organic Synthesis," H. Yamamoto, Ed., Wiley-VCH, Weinheim, 2000, p 395.

10. A. V. Yatsenko, L. A. Aslanov, M. Y. Burtsev, and E. A. Kravchenko, Zh. Neorg. Khim., 36, 2031 (1991).

11. D. Farcasiu, R. Leu, and P. J. Ream, J. Chem. Soc., Perkin Trans. 2, 427 (2001).

12. Polymerization of IBVE in the presence of butyl ethyl ether, and the discussions are described in the Supporting Information. 